\title{
Bivariate Analysis on Autism Therapy using Social Skills Training in SLB YPPA Padang
}

\author{
Ridhyalla Afnuhazi \\ Akademi Keperawatan Nabila, Padangpanjang, Indonesia \\ Email : ridhyallaafnuhazi@yahoo.co.id
}

\begin{abstract}
Number of persons with autism in the world range of $60.000-150.000$ autism occurred in children aged below 15 years. Therapy was given to improvement of social skills in autistic children Social Skills Training Therapy (SST). The purpose of this study was to determine bivariate analysis on the ability of Socialization Effects of SST for Autism Children (6 -12 years) in SLB Autism YPPA Padang 2015. Quasi - experimental design with one - group pre post test. The population in this study all children with autism aged 6-12 year, and samples were taken by convenience sampling 30 people. Univariate date processing techniques while the frequency distribution and central tedensy and Bivariate date processing techniques with paired $\mathrm{T}$ - test. Results of research abilities children with autism after therapy SST, and light weight characteristic factors of symptoms associated with social skills of children with autism. Suggestions can be submitted to the study of nursing in order to detect early signs of the symptoms experienced by children with autism so there is no sign of severe symptoms and train the socialization skills of children with autism with SST therapy.
\end{abstract}

Keywords : Bivariate analysis, Ability socialization, Social Skills Training, autistic children

\section{Introduction}

Autism is a pervasive development disorder in children that is characterized by disturbances and delays in the fields of cognitive, language, behavior, communication and social interaction (14). According to Yatim (2003) Autism is not a symptom of the disease but in the form of a syndrome or a collection of symptoms where there is a deviation of social development, language skills and concern for the surrounding, so that children with autism live in their own world(31).

Two factors cause autism, namely: Psychosocial factors, because of parenting and the theory of neuro-biologist disorders that mention neuroanatomic disorders or brain biochemical disorders, the main causes of autism are still being studied. Some of the factors that cause autism are: genetic factors, disorders of brain cell growth in the fetus, digestive disorders, heavy metal poisoning, auto-immune disorders, in children who experience pre-natal problems such as: Premature, postmatur, antenatal bleeding in the tricemester first, children born to mothers over the age of 35 years, and children with a history of labor that is not spontaneous. 
Signs and symptoms of children with autism ignore voice, vision, or events that involve them, usually the reaction is not in accordance with the situation or even there is no reaction at all (14). They avoid or do not respond to social contact, eyesight, touch of affection, playing with other children, and abnormal function traits in three areas: limited and repetitive social interaction, communication and behavior, so that children with autism have difficulty expressing feelings or his desire which resulted in the relationship with others to be disturbed.

Reviews of social competence and social skills development in autistic children consistently show deficiencies in social skills which significantly disrupt social relations (5). According to Melissa, et al. (2010) social problems are generally durable and can be difficult to change in children with autism, social challenges include: initiating, negotiating and maintaining social interactions, using and interpreting verbal and nonverbal behaviors in communication, social cognition (i.e., understanding other people's thoughts and emotions), empathy, and sharing affective experiences(17).

Obstacles experienced by autistic children such as not responding to social contact, communication results in autistic children unable to engage in socialization with their peers, especially in children with the developmental stages of school children (6-12 years) having the development task of fostering interaction and social relations with their peers. If a child with autism is late or does not get the intervention to adulthood, then the symptoms of autism are getting worse, even not overcome. So autistic children need some therapy to overcome it and can be like a normal child according to the health definition of all people have the same rights to welfare. According to Danuatmaja (2003) therapy for each child with autism varies depending on the particular symptoms it has (6).

Autistic children need special treatment and treatment early on, according to Danuatmaja (2003) there are several treatments that consist of medical therapy namely drugs such as melatonin, methylphenidate and non-medical therapies that can be done such as providing special education, occupational therapy, speech therapy and therapy language, makaton communication therapy, medical therapy, physical therapy by training their muscles, Applied Behavioral Analysis (ABA) to help recognize which behaviors are positive or negative, picture exchange communication system, which is a method of learning through pictures, expressing words through pictures which is easily captured by people with autism(6). For specialist therapy that can be applied, namely Cognitive Behavior Therapy (CBT) therapy, and Social Skill Training (SST). Therefore for the social skills of therapy used Social Skill Training (SST).

SST is one of the interventions with behavior modification techniques based on the principle of role playing, practice and feedback to improve the client's ability to solve problems for clients with difficulty behavioral disorders interacting, experiencing social phobia, and clients who experience anxiety (29). SST is designed to improve communication skills and social skills for someone who has difficulty in interacting including giving praise skills, complaining because they do not agree, rejecting other people's requests, exchanging experiences, demanding personal rights, giving advice to others, solving problems faced and cooperate with other people. There are four groups of social skills that are taught for individuals who experience obstacles in interpersonal relationships with others namely: the ability to communicate, establish friendships, engage in joint activities, and face difficult situations.

Doing SST therapy is needed by a nurse, mental health nurses continuously have an important role in identifying risky clients, reviewing the client's response to stress

61 IEKSAKTA: Berkala IImiah Bidang MIPA 
throughout their life span and in developing therapeutic communication aimed at healing clients (32). Peplau's theory which focuses on individuals, nurses and interactive processes that produce relationships between nurses and clients, suggests that nursing is an important, interpersonal and therapeutic process. According to King in his theory suggesting nurse client relationships are a means of providing nursing care, which is fostered through communication to assist clients in creating and maintaining adaptation to the environment (21). So that a nurse must have the skills and communication skills to do therapy.

Identifying and implementing evidence-based care for social disorders is very important in children with autism, ideally care must address both increasing skills for routine social engagement, increasing capacity to develop long-term, and the quality of social relations (17). The SST group explicitly teaches social skills in setting groups (i.e. with peers), and has been established as an effective way.

Research on SST has been carried out by Renidayati (2009) and Cognitive Behavioral Social Skills Training (CBSST) conducted by Jumaini (2010) in mental patients with social isolation, the results of both studies show that giving therapy is very significant in improving the ability of socialization to clients (23). A similar study was also conducted by Sambodo (2012) regarding the effect of SST on the skills of socialization and social anxiety of deaf adolescents(26).

The results of the study showed an increase in socialization skills of $8.38 \%$ and an average decrease in anxiety score of $8.97 \%$. it was concluded that there were significant differences in socialization skills and social anxiety scores in deaf adolescents before and after SST therapy. A similar study was conducted by Cotugno (2009) regarding "Social Competence and Social Skills Training and Intervention for Children with Autism Spectrum Disorders (ASD)", carried out in children aged 7-11 years. The results of the study showed that this approach could be effective in increasing core social deficits. in individuals with ASD(5).

In YPPA Padang Autistic School the number of autistic children has increased, based on data obtained by the number of autistic children in 2013 amounting to 54 people, in 2014 there were 56 people, and in 2015 there were 60 people with an age range of child and adolescent development . Efforts or therapies were carried out at YPPA Padang such as: Applied Behavioral Analysis (ABA) Therapy, sensory integration therapy, Hydrotherapy, speech therapy, relaxation therapy, play therapy, and socialization skills (social relations with peers).

At YPPA Padang there have been efforts or therapies in the ability to socialize namely to develop social relations with peers by teaching them how to get acquainted, from this method of acquaintance, only a few children with autism can carry out two-way communication or feedback between one child and those who others are characterized by eye contact, smiling, the ability to answer questions and the ability to ask questions. Many children cannot respond to socialization activities, only busy with themselves, even with absolutely no eye contact.

The results of observations on July 29, 2015, at YPPA were taught how to get acquainted, out of the 5 children observed, 3 children were unable to do verbal and nonverbal ways of getting acquainted. In establishing friendships also been taught, but autistic children are only taught how to help others, while for their own initiative or desire to ask for help autistic children at YPPA can not do it. In the implementation of group activities there have also been carried out by inviting children in interaction relationships

62 IEKSAKTA: Berkala IImiah Bidang MIPA 
(group activities) such as carrying out play therapy (jumping rope) but the results seen in the activity are assisted by 2 tutors holding rope and each child playing rope jumping while friends others only see, in conducting group activities to improve their socialization skills, it is recommended that children hold the rope.

Seeing the importance of socialization in everyday life and based on the above phenomena, where most autistic children are unable to socialize, the authors are interested in examining "The Effect of SST on the Ability of Socialization of Autism Children (6 - 12 Years) in YPPA Padang Autism SLB 2015".

The general objectives of this study are: It is known the effect of SST on the socialization skills of autistic children (6-12 years) in YPPA Padang Autistic SLB 2015. Special Purpose: to know the characteristics of autistic children (6-12 years) in YPPA Padang Autistic SLB, to know socialization skills autistic children (6-12 years) in YPPA Padang Autistic SLB before and after SST, the characteristic factors related to the socialization ability of autistic children (6-12 years) were identified in YPPA Padang Autonomous School.

\section{Methodology}

Research design is a model or method used by researchers to conduct a study that gives direction to the course of research. The design used in this study was "quasi experimental one-group pre-post test" with SST intervention and sampling was done by convenience sampling technique. The total number of autistic children in the YPPA Autonomous School SLB was 60 people with children and adolescence levels, of which 34 autistic children in the YPPA Autonomous School SLB and 30 respondents.

Data collection tool for Questionnaire A (Characteristics of Reponden): It is an instrument to obtain a characteristic description of respondents. Characteristics of response data entered in the A questionnaire sheet, consisting of 3 (three) statements, namely: Gender, age, level of education (class). Questionnaire B (Light Weight Symptoms): An instrument for measuring the mild weight of symptoms experienced by autistic children, this instrument uses ICD-10 (International Classification of Diseases, 1993) and DSM-IV (Diagnostic and Statistical Manual, 1994). Questionnaire C (Socialization Capability):

An instrument for measuring socialization skills in autistic children is made by researchers according to the circumstances of children with autism and evaluation of SST modules that have been carried out competency tests by Supervisors who have carried out SST research, implementation by observing. This instrument consists of 20 statements using the Gutman scale (yes or no) by giving a checlist to one answer, the answer is yes the value 1 and the answer is not the value 0. Questionnaire C (SST): The SST module for autistic children consists of 3 (three ) sessions, namely: Session 1 group orientation, assessment, and training in communication skills, session 2 exercises the ability to establish friendships, session 3 exercises the ability to engage in joint activities,

Univariate Analysis: Variables analyzed univariately in this study are factors that influence and characteristics of respondents in autistic children include: Gender, age and education, severity of symptoms, ability to socialize before and after intervention. Numerical data are age calculated for mean, median, standard deviation, minimum and maximum values, and 95\% confidence interval. For gender, education, symptom weight, implementation of SST, socialization skills in the form of categorical data by calculating 
percentages or proportions (frequency distribution). Presentation of each variable using a table and interpreted based on the results obtained.

\section{Bivariate Analysis of Characteristics of Respondents}

\begin{tabular}{lll}
\hline No & Characteristic & \multicolumn{1}{c}{ Type of Analysis } \\
\hline & Age & Independent T Test \\
Level of autism & Chi Square Test \\
& Sex
\end{tabular}

$\begin{array}{ll}\text { Education } & \text { Chi Square Test } \\ & \text { Chi Square Test }\end{array}$

Analysis of Differences Before and After Intervention

\begin{tabular}{llll}
\hline No & $\begin{array}{c}\text { Before } \\
\text { intervention }\end{array}$ & $\begin{array}{c}\text { After } \\
\text { Intervention }\end{array}$ & $\begin{array}{c}\text { Type of } \\
\text { Analysis }\end{array}$ \\
\hline Socialization & Socializatio & Paired \\
Skill & n Skill & t-test \\
\hline
\end{tabular}

\section{Results}

\section{Characteristics of Autistic Children Based on Gender, Education}

Gender, education, is categorical data so it is analyzed using frequency distributions which are combined into the same table. The results of the analysis of sex characteristics, education are presented in table 5.1

Table 5.1. Characteristic Distribution Based on Gender, Autism Child Education (6-12 Years) in Autism SLB Padang Potential Development Foundation (YPPA) in 2015 (n = 30)

\begin{tabular}{llll}
\hline Variable & Category & F & \% \\
\hline \multirow{2}{*}{ Sex } & Male & 25 & 83,3 \\
\cline { 2 - 4 } & Female & 5 & 16,7 \\
\hline \multirow{2}{*}{ Education } & Kindergaten & 4 & 13,3 \\
\cline { 2 - 4 } & Elementary & 26 & 86,7 \\
\hline
\end{tabular}

Based on table 5.1, it is known that the sex distribution of autistic children is mostly male, namely 25 people $(83.3 \%)$, the education level is mostly elementary school education, which is 26 people $(86.7 \%)$. 


\section{Characteristics of Autistic Children Based on Light Weight Symptoms}

Symptom light weight is categorical data so it is analyzed using frequency distribution which in its presentation is combined into the same table. The results of the analysis of the mild characteristics of the symptoms are presented in table 5.2

Table 5.2. Distribution of Characteristics Based on the Light Weight Symptoms of Autism Children (6-12 Years) in Autism SLB Padang Potential Development

Foundation (YPPA) in $2015(\mathrm{n}=30)$

\begin{tabular}{llll}
\hline Variable & Category & F & \% \\
\hline \multirow{3}{*}{ Level of autism } & Low & 4 & 13,3 \\
\cline { 2 - 4 } & Middle & 14 & 46,7 \\
\cline { 2 - 4 } Total & High & 12 & 40 \\
\hline
\end{tabular}

Based on table 5.2 it is known that the distribution of light weight symptoms of children with autism is the most moderate category, namely 14 people $(46.7 \%)$.

\section{Characteristics of Age-Based Autistic Children}

Age characteristics are numerical data which are analyzed by Central Tedensy or Explore to obtain the Mean, Standard Deviation, Minimum and Maximum values and Confident Interval (95\% CI).

Table 5.3. Characteristic distribution based on age of children with autism (6-12 years) in Autism SLB Padang Potential Development Foundation (YPPA) in 2015 ( $\mathrm{n}=30$ )

\begin{tabular}{lllllll}
\hline Variable & $\mathbf{n}$ & Mean & Median & SD & Min-Max & 95\% CI \\
\hline Age & 30 & 8,93 & 9 & 1,9 & $6-12$ & $8,22-9,65$ \\
\hline
\end{tabular}

Based on table 5.3 it is known that the average age of autistic children is 8.93 years with the youngest age 6 years and the oldest 12 years.

\section{Ability to Disseminate Autistic Children at YPPA Padang Autonomous School SLB Before SST is given}

Table 5.4. Distribution of Socialization Capabilities Before being given SST in Children with Autism (6-12 Years) at Autism SLB Padang Potential Development Foundation (YPPA) in $2015(\mathrm{n}=30)$

\begin{tabular}{llll}
\hline \multicolumn{1}{c}{ Variable } & Category & F & \% \\
\hline $\begin{array}{l}\text { Socialization ability before } \\
\text { SST }\end{array}$ & Low ability & 20 & 66,7 \\
\hline
\end{tabular}




\begin{tabular}{|c|c|c|c|}
\hline & High ability & 10 & 33,3 \\
\hline Total & & 30 & 100 \\
\hline
\end{tabular}

Based on table 5.4, it is known that the distribution of socialization abilities of autistic children before being given a poor SST is 20 people $(66.7 \%)$.

\section{Ability to Disseminate Autistic Children at YPPA Padang Autonomous School SLB After SST is given}

Table 5.5. Distribution of Socialization Capabilities After being given SST in Autism Children (6-12 Years) in Autism SLB Padang Potential Development Foundation (YPPA) in $2015(\mathrm{n}=30)$

\begin{tabular}{llll}
\hline Variabel & Category & F & \% \\
\hline Socialization ability after & Low ability & 14 & 46,7 \\
\cline { 2 - 4 } SST & High ability & 16 & 53,3 \\
\hline Total & & $\mathbf{3 0}$ & $\mathbf{1 0 0}$ \\
\hline
\end{tabular}

Based on table 5.5, it is known that the distribution of socialization capabilities of autistic children after being given SST is capable of as many as 16 people (53.3\%).

Differences in the Ability of the Autistic Children in the YPPA Padang Autonomous School SLB Before and After SST

Analysis of differences in the socialization abilities of autistic children in YPPA Autism SLB before and after being given an SST was carried out by a Dependent sample t-test (Paired t-test) which the results of the analysis are explained in table 5.6.

Table 5.6. Differences in Autism (6-12 Years) Children's Socialization Ability Before and After SST at the Autism SLB Padang Children's Development Foundation (YPPA) in $2015(n=30)$

\begin{tabular}{lllll}
\hline & SST & n & Mean & $\begin{array}{l}\text { P- } \\
\text { Value }\end{array}$ \\
\hline \multirow{2}{*}{ Socialization ability } & Before & 30 & 4,57 & \multirow{0}{*}{$\mathbf{0 , 0 1 2}$} \\
\cline { 2 - 5 } & After & & 7,87 & \\
\cline { 2 - 5 } & Difference & \multicolumn{2}{c}{3,3} & \\
\hline
\end{tabular}

Based on table 5.6 it is known that there is a significant difference between the average socialization ability of autistic children before being given an SST and after being given an SST in the Autism SLB Padang Children's Potential Development Foundation (YPPA) in 2015 which is 3.3 with p-value 0.012 . 
Characteristic Factors Associated with the Ability of Socializing Children with Autism in YPPA Padang Autistic SLB

\section{The Relationship between Gender and Autism Children's Socialization Ability}

Table 5.7 Relationship between Gender and Child Autism (6-12 Years) Dissemination Ability in Autistic SLB for Child Potential Development Foundation

\begin{tabular}{lllllll}
\hline \multirow{2}{*}{ Sex } & \multicolumn{2}{l}{ Socialization Ability } & & \multicolumn{2}{c}{ amounts } \\
\cline { 2 - 7 } & Low & & High & & n & \% \\
\cline { 2 - 7 } & $\mathrm{n}$ & $\%$ & $\mathrm{~N}$ & $\%$ & & \\
\hline Male & 11 & 44 & 14 & 56 & 25 & 100 \\
\hline Female & 3 & 60 & 2 & 40 & 5 & 100 \\
\hline Total & $\mathbf{1 4}$ & & $\mathbf{1 6}$ & & $\mathbf{3 0}$ & \\
\hline
\end{tabular}

Based on table 5.7 it is known that out of 25 autistic boys there are 14 people (56\%) who are able to socialize well. Of the 5 autistic girls there were 2 people (40\%) who were able to socialize.

After a statistical test was obtained, the result of Pvalue $=0.642$ means that there is no significant relationship between gender and the socialization ability of autistic children (6-12 years) at the 2015 Autism Potential Development Foundation (YPPA) Foundation in Padang.

\section{Relationship between Age and the Ability of Socializing Children with Autism}

Table 5.8. Relationship between Age and Child Autism (6-12 Years) Dissemination Ability in Autism SLB Padang Potential Development Foundation (YPPA) in 2015 (n = 30)

\begin{tabular}{|c|c|c|c|c|c|c|c|}
\hline & $\begin{array}{l}\text { Socialization } \\
\text { ability }\end{array}$ & $\mathbf{n}$ & Mean & SD & SE & $\mathbf{T}$ & P-Value \\
\hline \multirow{2}{*}{ Age } & Low & 14 & 9,64 & 2,13 & 0,57 & \multirow{3}{*}{1,998} & \multirow{3}{*}{0,055} \\
\hline & High & 16 & 8,31 & 1,49 & 0,37 & & \\
\hline & & 30 & $-1,33$ & $-0,64$ & & & \\
\hline
\end{tabular}

Based on table 5.8, the result of Pvalue $=0.055$ means that there is no significant relationship between age and the ability to disseminate autism children (6-12 years) at the Autism Development Center for Children Potential Development (YPPA) Padang in 2015. 
The Relationship between Education and the Ability of Socializing Children with Autism

Table 5.9. The Relationship between Education with the Ability of Socialization of Autism Children (6-12 Years) in Autism SLB Padang Potential Development Foundation (YPPA) in $2015(\mathrm{n}=30)$

\begin{tabular}{lllllll}
\hline \multirow{2}{*}{ Education } & \multicolumn{2}{l}{ Socialization ability } & \multicolumn{3}{l}{ Amounts } & \multirow{2}{*}{ P-value } \\
\cline { 2 - 7 } & Low & \multicolumn{1}{l}{ High } & n & \% & \\
\cline { 2 - 7 } & $\mathbf{N}$ & $\mathbf{\%}$ & $\mathbf{n}$ & $\mathbf{\%}$ & & \\
\hline Kindergaten & 1 & 25 & 3 & 75 & 4 & 100 \\
\hline Elementary & 13 & 50 & 2 & 50 & 26 & 100 \\
\hline Total & $\mathbf{1 4}$ & & $\mathbf{5}$ & & $\mathbf{3 0}$ & \\
\hline
\end{tabular}

Based on table 5.9, it is known that out of 4 autistic children with TK education there are 3 people $(75 \%)$ who are able to socialize well. Of the 26 autistic children with elementary education, only 13 people $(50 \%)$ were able to socialize well.

After a statistical test was obtained, the result of Pvalue $=0.602$ means that there is no significant relationship between education and the socialization skills of autistic children (6-12 years) at the 2015 Autism Potential Development Foundation (YPPA) Foundation in Padang.

Relationship between Light Weight Symptoms and the Ability to Promote Autistic Children

Table 5.10. The Relationship between the Mild Weight of Symptoms and the Ability of Socializing Children with Autism (6-12 Years) in Autism SLB Padang Potential Development Foundation (YPPA) in $2015(\mathrm{n}=30)$

\begin{tabular}{|c|c|c|c|c|c|c|c|}
\hline \multirow{3}{*}{ Level of Autism } & \multicolumn{4}{|c|}{ Socialization Ability } & \multicolumn{2}{|c|}{ Amounts } & \multirow{3}{*}{ P-value } \\
\hline & \multicolumn{2}{|c|}{ Low } & \multicolumn{2}{|c|}{ High } & \multirow[t]{2}{*}{$\mathbf{n}$} & \multirow[t]{2}{*}{$\%$} & \\
\hline & $\mathrm{n}$ & $\%$ & $\mathrm{n}$ & $\%$ & & & \\
\hline Low & 0 & 0 & 4 & 100 & 4 & 100 & \\
\hline Middle & 2 & 14,3 & 12 & 85,7 & 14 & 100 & 000 \\
\hline High & 12 & 100 & 0 & 0 & 12 & 100 & 0,000 \\
\hline Total & 14 & & 16 & & 30 & & \\
\hline
\end{tabular}

Based on table 5.10 it is known that out of 4 autistic children who have mild symptoms of mild symptoms there are 4 people (100\%) who are able to socialize. Of the 14 autistic children who have mild symptoms, there are 12 people $(85.7 \%)$ who are able to socialize. And of the 12 autistic children who have mild severe symptoms, no one is able to socialize.

68 IEKSAKTA: Berkala IImiah Bidang MIPA 
After a statistical test was obtained, the result of Pvalue $=0,000$ means that there is a significant relationship between the mild weight of symptoms and the socialization ability of autistic children (6-12 years) at the 2015 Autism Potential Development Foundation (YPPA) Padang Foundation.

\section{Discussion}

\section{Characteristics of Autistic Children Against Socialization Ability}

The characteristics of autistic children in this study included gender, age, education and mild symptoms. The sex of autistic children in this study was dominated by men as many as 25 people $(83.3 \%)$. This is the same as the research conducted by Baim (2006) in which the sex of most autistic children is male $(60 \%)$.

Autism disorders are four times more common in boys than girls, with a ratio of 3: 1 for boys and girls (Besty, 2013). Boys are more susceptible to autism syndrome than girls, because boys have the hormone testosterone which has an opposite effect on the female hormone estrogen, testosterone hormone inhibits RORA (alpha retinoic acidrelated orphan receptor) which functions to regulate brain function, while estrogen increases the performance of RORA. The male population that is more than the women in the study location is also a factor that results in a greater number of men in the research subject. This also proves that people with autism suffer from many male children. The overall age of autistic children ranged from 6 to 12 years with a mean value of 8.93. This is the same as a study conducted by the United States Center for Disease Control (CDC) in 2008, stating that the ratio of autism to 8-year-olds diagnosed with autism is 1:80.

This is in accordance with the theory put forward by that school-age children are known as the working phase, this period is between the ages of 6-12 years is the childhood begins to enter the more formal school world, in children schools grow a sense of independence of children, children want to be involved in the tasks carried out to completion.

In the opinion of researchers, in this study the age of children with autism between 6-12 years of age where the most children at the age of 8 years and 9 years, at this age is the stage of development of school children. Where this age children begin to enter a more formal school world and have various forms of development such as interacting, learning achievement, playing a role in group activities.

Most of the 26 people (86.7\%) autistic children have elementary school education. This is the same as the research conducted by Sintia (2012) that most children with special needs have low education levels.

According to Article 15 of Law No. 20 of 2003 concerning National Education System, that the type of education for children with special needs is Special Education. Article 32 (1) Law No. 20 of 2003 limits that special education is education for students who have a level of difficulty in following the learning process due to physical, emotional, mental, social, and / or potential intelligence and special talents. Technical education service types of Education Specifically for students with disabilities or students who have extraordinary intelligence can be held on an inclusive basis or in the form of special education units at the primary and secondary education level. So Special Education only exists at the level of primary and secondary education, while in SLB the distribution of education is based on therapeutic classes namely low and high. 
According to the analysis of researchers, the history of education in autistic children is also one of the social predisposing factors because the education of autistic children is a benchmark in accepting something that is taught. Autistic children are children who need special education, so many autistic children who have low education. This is also caused by the length of therapy, because there are autistic children who have just entered therapy school so their education starts from a low level.

The type of symptoms experienced by autistic children in this study were mostly at a moderate level (46.7\%). This is the same as the research conducted by Rika (2008), the type of symptoms experienced by autistic children is moderate $(47.5 \%)$. According to Yatim (2003) Autism is not a symptom of the disease but in the form of a syndrome or a collection of symptoms where there is a deviation of social development, language skills and concern for the surrounding, so that children with autism live in their own world. Signs and symptoms of children with autism ignore voice, vision, or events that involve them, usually the reaction is not in accordance with the situation or even there is no reaction at all (17).

According to the analysis of researchers, the signs and symptoms of autistic children they avoid or do not respond to social contact or interact, eyesight, touch of affection, communication, and behavior are limited and repetitive, so that children with autism have difficulty expressing feelings and desires that lead to relationships with others become disturbed. This can affect treatment because the type of symptoms experienced is an indicator of the success of the therapy given.

\section{Ability to socialize Autistic Children}

The ability to socialize in autistic children before the intervention is mostly in the less able to socialize, namely 20 people $(66.7 \%)$. This is the same as the research conducted by Sisiliana (2013) where the socialization ability of autistic children before being given treatment in the category of underprivileged (66.7\%).

Samsu Yusuf (in Budiamin et al., 2000) states that socialization is the achievement of maturity in social relations, social development is defined as a learning process to adjust to group norms, morals and traditions merge into a unity of mutual communication and cooperation. According to Judarwanto (2006) autistic children have problems or disorders in the field: Disorders in verbal communication and non verbal includes language skills experiencing delays or utterly unable to speak, using words without connecting with the meaning commonly used, communicating using body language and can only communicate for a short period of time, as well as disruptions in the field of social interaction including interference with refusing or avoiding face to face.

According to the analysis of researchers, socialization skills in autistic children are mostly less capable as we know children with the developmental stages of school age have the ability to interact, play a role in group activities but in autistic children the ability to socialize is very inversely like they are unable to form social relationships or develop communication normal, resulting in children becoming isolated from human contact and immersed in their own world which is expressed in interests and behaviors that are fixated and repeated. This can be caused by disorders of the central nervous system, especially experiencing a reduction in the cerebellum (lobe VI-VII reduction of purkinje cells) which can cause disruption of the process of channeling information between the brain, structural abnormalities at the emotional center.

70 |EKSAKTA: Berkala IImiah Bidang MIPA 


\section{Effect of SST on the Ability of Socializing Children with Autism}

The ability to socialize in autistic children before being given an SST is on average at a poor level but there are some autistic children who are able to socialize. While the ability of autistic children after being given SST increased significantly with p-value 0.012 .

A similar study was conducted by Cotugno (2009) regarding "Social Competence and Social Skills Training and Intervention for Children with Autism Spectrum Disorders (ASD)", carried out in children aged 7-11 years. The results of the study showed that this approach could be effective in increasing core social deficits. in individuals with ASD. This is in line with the research conducted by Renidayati (2009) and Cognitive Behavioral Social Skills Training (CBSST) conducted by Jumaini (2010) in psychiatric patients with social isolation, the results of both studies show that giving therapy is very significant in increasing the ability of socialization to clients .

According to Cartledge and Milbun (1995, in Chen, 2006), SST is an ability that can be learned by someone so that the person interacts by giving a positive response to the environment and reducing the negative response that might be present to him. Kneisl (2004) states that SST methods are based on social principles of learning and use roleplaying behavior techniques, practices and feedback to improve problem-solving skills.

According to the analysis of researchers, the ability to socialize in autistic children after being given SST has increased ability both verbal and non verbal communication skills (such as eye contact, dealing, shaking hands, smiling, greeting, introducing oneself), making friendships (such as giving help, asking help, say thank you), engage in joint activities (focus on the game, counting, congratulating). Improvement of socialization skills in autistic children occurs because in SST therapy autistic children are given as many as 3 (three) exercises namely communication skills, establishing friendships and doing joint activities as much as $3 \mathrm{x}$ in each session of SST implementation with modeling methods, role models, feed back, transfer training. This involves the ability to start and maintain positive and mutually beneficial interactions. Whereas in the underprivileged stage, a lot of activities occur with children, it is difficult to determine this winner can be caused by the characteristics of autistic children such as gender, age, level of education, and the mild weight of symptoms experienced by autistic children.

\section{Characteristic Factors Associated with the Dissemination Ability of Autistic Children}

\section{The Relationship between Gender and Autism Children's Socialization Ability}

In this study, results were obtained from 25 boys who were able to socialize after being given SST as many as 14 people (56\%) and from 5 girls who were able to socialize after being given SST as many as 2 people (40\%). Chi-Square statistic test obtained $\mathrm{p}$ value of 0.642 indicating that there was no significant relationship between sexes with the socialization ability of autistic children.

Experts argue that the quantity of language vocabulary mastered by girls is greater than that of boys. This is due to the difference between the male brain and the female brain in terms of its shape, that is, the left hemisphere in the female brain is thicker than 
the right hemisphere. In its development boys are slower to learn to speak when compared to girls). In addition, boys' sentences are shorter and the vocabulary is less than girls.

According to the analysis of the researchers, in the study there was no sex relationship with the ability to socialize, this could also be influenced by the severity and severity of symptoms experienced by autistic children and the number of boys more than girls. Although there is no relationship but from the results of the questionnaire observed there is an increase in the socialization ability of autistic children before intervention and after intervention, this can be seen from aspects of the value of children with male gender as many as 25 people before intervention is only 5 people $(20 \%)$ who were able to introduce themselves, after being intervened, increased to 16 people $(64 \%)$. While children with female sex as many as 5 people before the intervention only 1 person (20\%) were able to introduce themselves, after doing 3x interventions they experienced an increase of 2 people (40\%) who were able to introduce themselves and other points such as: position when communicating with each other face to face (point 3), shake hands (point 4), ask for help (point 10).

\section{Relationship between Age and the Ability of Socializing Children with Autism}

In this study t-independent statistical tests obtained a difference in mean value of 1.33 between the age of autistic children who were able to socialize and those who were less able to socialize with a p-value of 0.055 indicating that there was no significant relationship between age and ability to socialize. This is the same as the Aida Research (2013) regarding "Analysis of Factors that Influence the Progress of Autistic Child Therapy" in getting results there is no significant relationship between age and the progress of therapy in autistic children.

Stuart and Laraia (2008) state that age is related to one's experience in dealing with various types of stressors, the ability to utilize sources of support and skills in coping mechanisms. According to the analysis of the researchers, in this study showed that there was no difference in the socialization abilities of autistic children of various ages, in this study the average age of autistic children ranged from 6 to 12 years. Ages with the developmental stages of school children (6-12 years) have a developmental task of fostering interaction and social relations with their peers, whereas in autistic children aged at the school development stage they do not interact, communicate, carry out activities this group can be influenced by various light weight symptoms experienced by autistic children, anatomical abnormalities in the brain that cause developmental disorders, emotions, speech delays, impaired concentration,

If children with autism are late or do not get intervention into adulthood, then the symptoms of autism are getting worse, not even overcome. Although there is no relationship but from the results of the questionnaire observed there is an increase in the socialization skills of autistic children before intervention and after intervention, this can be seen from aspects of value such as eye contact, face to face, shake hands, introduce yourself.

\section{The Relationship Between Education and the Ability of Socializing Children with Autism}

In this study, it was obtained from 4 autistic children who were educated in TK there were 3 people ( $75 \%$ ) who were able to socialize. And of the 26 highly educated 
people there were 13 people (50\%) who were able to socialize. The Chi-Square statistical test obtained a p-value of 0.602 indicating that there was no significant relationship between education and the socialization capabilities of autistic children. This is the same as Sintia (2012) 's study of "Play Therapy: Cooperative Play with Puzzles to Improve the Socialization Ability of Mental Retarded Children" indicating that there is no significant relationship between the level of education of children with special needs and the ability to socialize.

Children's socialization abilities are influenced by children's education, children's active role, parental education, parents' active role, and environment (Gupte 2004). Every child is able to have optimal socialization skills if he gets the right stimulation. In each phase of growth, children need stimulation to develop their mental abilities and socialization. Children after being given stimulation are able to perform optimal developmental stages (Fabiola 2006). Education for autistic children can be either a special school or a place of therapy. Children's education can also influence their ability to socialize, because this place requires them to be able to communicate and interact well (Survina 2005). Children who are able to learn well will have the knowledge and information to be able to adapt well.

According to Notoatmojo (2007) someone who has a high level of education will be easier to receive information, easy to understand and easy to solve problems. While the low level of education will cause a person to experience stress more easily than those who have a higher level of education. According to Loucknotte (2006) a person's level of education can affect the ability to hear and absorb information obtained, solve problems, change behavior and change lifestyle. This is in accordance with the expression of Kopelowicz (2002) which states that the higher education and knowledge of a person will be positively correlated with coping skills possessed.

In the opinion of the researcher, the above theory is not in line with the research that has been carried out by researchers where in this study shows that the level of education does not affect the socialization skills of autistic children, it is indicated that there are children with less education who are more able to socialize than this highly educated influenced by motivation, the duration of therapy that has been implemented, the mild severity of symptoms experienced by autistic children.

Although there is no relationship but from the results of the questionnaire observed there is an increase in the socialization ability of autistic children before intervention and after intervention, this can be seen from aspects that are rated at a low ability level of 22 people before intervention is only 5 people $(22,7 \%)$ who were able to introduce themselves, after doing $3 \mathrm{x}$ interventions they experienced an increase to 16 people $(72.7 \%)$ who were able to introduce themselves and other points such as: positions when communicating facing each other (point 3), shaking hands (point 4 ), ask for help (point 10).

\section{Relationship between Symptom Specific Gravity and Autism Children's Socialization Ability}

In this study the results of 4 autistic children who had mild symptoms to 4 people $(100 \%)$ were able to socialize. Of the 14 people who have moderate symptoms there are 12 people $(85.7 \%)$ able to socialize And from 12 people who have severe symptoms found to 12 people $(100 \%)$ are less able to socialize. Test Chi-Square statistics obtained p-value 0,000 indicates that there is a significant relationship between the gravity of the

73 IEKSAKTA: Berkala IImiah Bidang MIPA 
symptoms and the socialization ability of autistic children. This is the same as Rika's research (2008) which shows that there is a significant relationship between the specific gravity of the symptoms and the implementation of therapy.

According to Yatim (2003) Autism is not a symptom of the disease but in the form of a syndrome or a collection of symptoms where there is a deviation of social development, language skills and concern for the surrounding, so that children with autism live in their own world. Signs and symptoms of children with autism ignore voice, vision, or events that involve them, usually the reaction is not in accordance with the situation or even there is no reaction at all (Judarwanto, 2006).

According to the analysis of researchers, this study shows that there is a relationship between the gravity of the symptoms and the ability to socialize autistic children. It is proven that autistic children who have mild symptoms are able to communicate verbally and non-verbally (such as eye contact, smile, face to face, shake hands, say hello) ), making friends (asking for help, giving help, thanking), engaging in joint activities (focusing on playing, counting, congratulating) while autistic children with severe symptoms are unable to socialize but after $3 \mathrm{x}$ interventions in each session there are also improvement in communication skills such as eye contact, face to face, shake hands.

\section{Conclusion}

The Conclusion in this reseacrh are (1) Characteristics of autistic child respondents, namely the average age of autistic children 8.93, most of the male sex, elementary school education, and mild symptoms are in the moderate range; (2) The socialization ability of autistic children before being given SST therapy experienced a significant increase after being given SST therapy; and (3) Characteristics of respondents with severe autism symptoms associated with the ability to socialize children with autism (6-12 years) at YPPA Padang Autonomous School.

\section{References}

[1] Arikunto, S. (2005). Prosedur Penelitian : Suatu Pendekatan Praktik. Edisi revisi. Jakarta : Rineka Cipta.

[2] Budhiman, M. (2001). Langkah Awal Menanggulangi Autisme. Jakarta: Nirmala.

[3] Budiamin, dkk. (2006). Perkembangan Peserta Didik. Bandung : UPI PRESS.

[4] Chen, K, \& Walk. (2006). Social Skills Training Intevension for Student with Emotional/ Behavioral Disorder : A Literature Review from American Perspective. www.ccbd.net/dokuments/bb/BB.15(3)\%social\% 20 skills pdf. Diakses pada tanggal 14 Juni 2015.

[5] Cotugno, A.J. (2009). Social Competence and Social Skills Training and Intervention for Children with Autism Spectrum Disorders. Published online : 14 April 2009 Springer Science+Business Media, LLC.

[6] Danuatmaja. (2003). Faktor Penyebab Autisme. http://health.kompas.com/read/2011/01/11/09501535/Lima.Faktor.Penyebab.Au tisme.Diakses pada tanggal 10 Juni 2015.

[7] Efendi, dkk. (2013). Gambaran Faktor Pre Natal Sebagai Penyebab Autis Di Sekolah Anak Khusus Kembang Mekar Desa Kepanjen Kecamatan Jombang

74 IEKSAKTA: Berkala IImiah Bidang MIPA 
Kabupaten Jombang.

[8] Erika, K. Autisme di Indonesia Terus Meningkat. http://lifestyle.okezone.com/read/2015/04/02/481/1128312/autisme-di-

indonesia-terus-meningkat.

[9] Handoyo, Y. (2003). Autisma. Jakarta: Bhuana Ilmu Populer.

[10] Hapsari, M.I \& Hasanat, N.U. (2000). Efektifitas Pelatihan Keterampilan Sosial pada Remaja dengan Gangguan Kecemasan. www.Jurnal.ump.ac.id/index.php/psikologi/article/view. Diakses pada tanggal 14 Juni 2015.

[11] Hartika, Sintia. (2012). Terapi Bermain : Cooperative Play Dengan Puzzle Meningkatkan Kemampuan Sosialisasi Anak Retardasi Mental. Tidak dipublikasikan.

[12] Herbert, J.D \& Kasdan, T.B. (2001). Social Anxiety Disorder in Childhood and Adolescence : Current Status and Future Directions. www.mason.gmu.edu/tkashdan/childsad/pdf. Diakses pada tanggal 14 Juni 2015.

[13] Hidayat, A.A. (2007). Metode Penelitian Keperawatan dan Teknik Analisa Data. Jakarta : Salemba Medika.

[14] Judarwanto W (2010). http://puterakembara.org/archives10/00000055.shtml. Di akses pada tanggal 14 Juni 2015.

[15] Jumaini. (2010). Pengaruh Cognitive Behavioral Social Skills Training (CBSST) terhadap Kemampuan bersosialisasi di BLU RS Dr. H. Marzzoeki Mahdi Bogor. Tesis FIK-UI. Tidak dipublikasikan.

[16] Kneils, C.R., Wilson, H.S., \& Trigoboff, E. (2004). Contemporary Psychiatry Mental Health Nursing. New Jersey : Pearson Prentice Hall.

[17] Melissa, E. (2010). The Efficacy of a Social Skills Group Intervention for Improving Social Behaviors in Children with High Functioning Autism Spectrum Disorders. Published online Springer Science+Business Media, LLC.

[18] Minropa, Aida. (2013). Analisis Faktor - Faktor Yang Mempengaruhi Kemajuan Terapianak Autis Di Kota Padang. Tidak dipublikasikan.

[19] Notoatmojo, S. (2005). Metodologi Penelitian Kesehatan. Jakarta: PT Rineka Cipta.

[20] Peeters, T. (2004). Autisme. Jakarta: Dian Rakyat.

[21] Potter dan Perry. (2005). Fundamental Keperawatan Volume I Edisi 4. Jakarta: EGC.

[22] Prawitasari, dkk. (2002). Psikoterapi Pendekatan Konvensional dan Kontemporer. Yogyakarta: Pustaka Pelajar dan Unit Publikasi Fakultas Pikologi UGM.

[23] Renidayati. (2008). Pengaruh Social Skill Training (SST) pada Klien Isolasi Sosial di RSJ H.B Saanin Padang Sumatera Barat. Tesis FIK- idak dipublikasikan.

[24] Sabri, Rika. (2008). Pengaruh Pendekatan Home Base Program Dalam Pemberian Terapi Metoda Applied Behaviour Analysis (ABA) Terhadap Kemajuan Penderita Autisma di Sekolah Autisma Kota Padang. Tidak dipublikasikan.

[25] Sabri, Rika dkk. (2009). Pengaruh Terapi Autis Terhadap Kemajuan Anak Autis di Sekolah Khusus Autisme di Kota Padang. Tidak dipublikasikan.

[26] Sambodo, Sriadi. (2012). Pengaruh SST terhadap keterampilan sosialisasi dan

75 IEKSAKTA: Berkala IImiah Bidang MIPA 
social anxiety remaja tunarungu di SLB Kabupaten Wonosobo.Tesis FIK-UI.

[27] Sastroasmoro, S \& Ismael, S, . (2010). Dasar-Dasar Metodologi Penelitian Klinis. Edisi ke-3. Jakarta : Sagung Seto.

[28] Sisiliana. (2013). Pengaruh Metode Aba (Applied Behaviour , is): Kemampuan Bersosialisasi Terhadap Kemampuan Interaksi Sosial Ana : di SLB TPA (Taman Pendidikan Dan Asuhan) Kabupaten Jember. Tidak dipublikasikan.

[29] Stuat, G.W. (2009). Principles and practice of pshychiatric nursing. Louis Missouri :Mosby Elsevier.

[30] Yatim, F. (2003). Autisme Suatu Gangguan Jiwa Pada Anak-Anak. Jakarta: Pustaka Populer Obor.

[31] Yosep, I. (2009). Keperawatan Jiwa. Bandung: Refika Aditama.

[32] Worskshop Keperawatan Jiwa ke-8. (2014). Modul Terapi Keperawatan Jiwa. Depok : FIK-UI. 